\title{
New roughage source of Pennisetum purpureum cv. Mahasarakham utilization for ruminants feeding under global climate change
}

\author{
Chaowarit Mapato ${ }^{1}$ and Metha Wanapat ${ }^{1, *}$
}

* Corresponding Author: Metha Wanapat Tel: +66-43202368, Fax: +66-43202368,

E-mail: metha@kku.ac.th

${ }^{1}$ Tropical Feed Resources Research and Development Center (TROFREC), Department of Animal Science,

Faculty of Agriculture, Khon Kaen University, Khon Kaen 40002, Thailand

ORCID

Chaowarit Mapato

https://orcid.org/0000-0002-9368-3298

Metha Wanapat

https://orcid.org/0000-0002-7633-052X

Submitted Mar 15, 2018; Revised Apr 19, 2018; Accepted May 9, 2018
Objective: As the climate changes, it influences ruminant's feed intake, nutrient digestibility, rumen methane production and emission. This experiment aimed to evaluate the effect of feeding Sweet grass (Pennisetum purpureum cv. Mahasarakham; SG) as a new source of good quality forage to improve feed utilization efficiency and to mitigate rumen methane production and emission.

Methods: Four, growing crossbred of Holstein Friesian heifers, 14 months old, were arranged in a $4 \times 4$ Latin square design to receive four dietary treatments. Treatment 1 (T1) was rice straw (RS) fed on ad libitum with $1.0 \%$ body weight (BW) of concentrate (C) supplementation (RS/1.0C). Treatment 2 (T2) and treatment 3 (T3) were SG, fed on ad libitum with $1.0 \%$ and $0.5 \% \mathrm{BW}$ of concentrate supplementation, respectively (SG/1.0C and SG/0.5C, respectively). Treatment 4 (T4) was total Sweet grass fed on ad libitum basis with non-concentrate supplementation (TSG).

Results: The results revealed that roughage and total feed intake were increased with SG when compared to RS ( $\mathrm{p}<0.01$ ) while TSG was like RS/1.0C treatment. Digestibility of nutrients, nutrients intake, total volatile fatty acids (VFAs), rumen microorganisms were the highest and $\mathrm{CH} 4$ was the lowest in the heifers that received SG/1.0C ( $\mathrm{p}<0.01)$. Total dry matter (DM) feed intake, digestibility and intake of nutrients, total VFAs, $\mathrm{NH}_{3}-\mathrm{N}$, bacterial and fungal population of animals receiving SG/0.5C were higher than those fed on $\mathrm{RS} / 1.0 \mathrm{C}$. Reducing of concentrate supplementation with SG as a roughage source increased $\mathrm{NH}_{3}-\mathrm{N}$, acetic acid, and fungal populations, but it decreased propionic acid and protozoal populations $(\mathrm{p}<0.05)$. However, ruminal $\mathrm{pH}$ and blood urea nitrogen were not affected by the dietary treatments ( $>0.05)$.

Conclusion: As the results, SG could be a good forage to improve rumen fermentation, decrease methane production and reduced the level of concentrate supplementation for growing ruminants in the tropics especially under global climate change.

Keywords: Forage Utilization; Sweet Grass; Feed Quality; Global Climate Change, Ruminants

\section{INTRODUCTION}

As global warming occurs, it has been a topic of concern and significance for all, especially those engaged in ruminant production. Feed resources and feeding manipulation are of paramount importance to improve rumen fermentation efficiency and reduce methane production, which can affect global warming $[1,2]$. Roughages are a very important feed resource for feed utilization in ruminants. Among numerous sources, rice straw is an abundantly available feed resource in the sub-tropical and tropical area. Its low protein and high cellulose-lignin content can reduce nutrient digestibility, feed intake and production performances. In general, heifers are traditionally fed a high amount of roughage and a moderately low energy diet. However, low quality roughage feeding requires a high level of concentrate supplementation to compensate for the low nutrient intake which would result in decreased 
feed efficiency of the animal and increased production costs. Roughage has been considered a low cost source of nutrients and grain has been considered expensive, as a result, roughage use often was maximized to reduce feed cost. In addition, the other benefits of roughage included improved ruminal $\mathrm{pH}$, overall rumen health, milk components, and economic return [3-5]. However, the quality of roughage is an important factor affecting rumen fermentation and feed degradation [6]. High quality roughage will allow the rumen microbes to increase the digestion of roughage itself, supplying more nutrients to the animal which could reduce the concentrate supplementation [3]. Furthermore, high quality forage diet feeding can increase the fiber physical effectiveness that could stimulate the cud chewing activity and decrease the risk of ruminal acidosis. Nevertheless, good or high quality roughage is required in order to reduce concentrate supplementation while maintaining the animal performances $[4,7]$.

Previous researchers reported that using rich and locally available feed resources with good nutritive composition, such as cassava hay, corn, forage sorghum and tropical legumes, as the alternative forage could reduce concentrate supplementation with improved feed utilization in ruminants $[4,5,8,9]$. Currently, Mapato and Wanapat [10] found that Sweet grass (Pennisetum purpureum cv. Mahasarakham; SG), a dwarf Napier grass variety, contains a high nutrient composition, especially in crude protein (15.2\% dry matter [DM]), non-fiber carbohydrate (NFC, $12.1 \% \mathrm{DM}$ ) and is low in acid detergent fiber (ADF) content $(34.9 \% \mathrm{DM})$. These characteristics are achieved when the plant is harvested at 42 days of growth when there is a high leaf to stem ratio leading to a high DM and organic matter degradability, and lower in vitro gas production when compared with other tropical grasses namely Ruzi, Guinea, and Napier Pakchong1. At a higher ratio of roughage to concentrate (80:20), SG has similar in in vitro degradability and gas production to the diet containing Guinea at a 60:40 ratio, in which Guinea grass was the lowest quality while SG was the highest quality forage. It appeared that SG can reduce concentrate supplementation. Nevertheless, more investigation on feed intake, rumen fermentation, and nutrient utilization are still required, especially on feed utilization with reduced concentrate supplementation. Therefore, the aim of this experiment was to determine the use of SG as a good quality forage to reduce the amount of concentrate supplementation in growing crossbred Holstein dairy in hot tropical conditions.

\section{MATERIALS AND METHODS}

\section{The experimental area}

This experiment was performed at the Ruminant Nutrition and Metabolism Research Center, Tropical Feed Resource Research and Development Center (TROFREC), Department of Animal Science, Faculty of Agriculture, Khon Kaen Uni- versity, Khon Kaen, Thailand. The experimental methods and all animals were allowed by the Khon Kaen University Animal Ethics Committee, ancillary to the Ethic of Animal Experimentation of National Research Council of Thailand.

\section{Animals, diets and experimental design}

Four crossbred Holstein-Frisian heifers (mean \pm standard deviation) of body weight [BW]; $203 \pm 3.2 \mathrm{~kg}$ as initial weight); 14 months old were randomly assigned in a $4 \times 4$ Latin square design. Heifers received four dietary treatments with different roughage sources and concentrate supplementation levels. Rice straw (RS) and fresh SG were the roughage source and were fed on ad libitum basis. Levels of concentrate (C) supplementation were $1.0 \%, 0.5 \%$, and $0 \%$ of BW. Four treatments are as follows: T1 was RS with $1.0 \% \mathrm{BW}$ of $\mathrm{C}$ (RS/1.0C); T2 and T3 were SG with $1.0 \%$ and $0.5 \%$ BW of C, respectively (SG/1.0C and SG/0.5C, respectively). T4 was total SG fed on ad libitum (TSG). Experimental feed ingredients of the concentrate, nutrient composition of all experimental feeds are presented in Table 1. All experimental animals were treated with vitamin $\mathrm{A}, \mathrm{D}_{3}$, E injection and deworming before imposing the respective treatments.

The experiment was carried out for four periods with each period consisting of 21 days. The first 14 days were for animal adaptation, while the last 7 days for sample collection. Animals were raised in individual pen and received the experimental diets twice a day at $7.00 \mathrm{am}$ and $3.00 \mathrm{pm}$ with free water and mineral lick blocks. Fresh SG was cut around 45 days of growth and chopped daily before feeding. The difference between

Table 1. Feed ingredients of the concentrate and chemical composition of the feeds

\begin{tabular}{|c|c|c|c|}
\hline Items & Concentrate & Sweet grass & Rice straw \\
\hline \multicolumn{4}{|l|}{ Ingredients (\%, fresh basis) } \\
\hline Cassava chip & 60.0 & - & - \\
\hline Rice bran & 10.0 & - & - \\
\hline Coconut meal & 15.0 & - & - \\
\hline Palm meal & 10.0 & - & - \\
\hline Urea & 1.5 & - & - \\
\hline Molasses & 2.0 & - & - \\
\hline Sulfur & 0.5 & - & - \\
\hline Mineral mixture & 0.5 & - & - \\
\hline Salt & 0.5 & - & - \\
\hline Total & 100.0 & - & - \\
\hline \multicolumn{4}{|l|}{ Chemical composition } \\
\hline \multirow[t]{2}{*}{ Dry matter (\%) } & 91.1 & 13.2 & 92.7 \\
\hline & & $-\%$ of dry matte & \\
\hline Crude protein & 14.1 & 14.7 & 2.8 \\
\hline Ether extract & 2.8 & 2.3 & 1.4 \\
\hline Acid detergent fiber & 12.9 & 33.1 & 46.8 \\
\hline Neutral detergent fiber & 18.7 & 55.7 & 75.8 \\
\hline Ash & 7.5 & 9.8 & 16.3 \\
\hline Non fiber carbohydrate & 52.9 & 15.2 & 3.7 \\
\hline
\end{tabular}


roughage quantity allocated and refusals were voluntary feed intake of roughages for every day of the trial. Concentrates were fed according to the respective treatments.

Sampling procedures and experiment analysis methods All procedures and feed details collection, rumen fluid, blood samples and rumen methane calculation were done according to all procedures reported in Wanapat et al [11]. All samples such as the concentrate, rice straw, SG and fecal samples were taken at every period during the last 7 days. The samples were separated into two parts, the first part was used to analyze for $\mathrm{DM}$. The second part was for crude protein (CP), ether extract (EE) and ash, using the technique of AOAC [12]. Neutral detergent fiber $(\mathrm{NDF})$ and $\mathrm{ADF}$ were analyzed by the technique of Van Soest et al [13]. The NFC was calculated according to the equation of NRC [14] which $\% \mathrm{NFC}=100-(\mathrm{NDF}+\mathrm{CP}+$ $\mathrm{EE}+$ Ash).

Rumen fluid was taken at 0 and 4 hours after feeding on the last day of each period. Approximately, $200 \mathrm{~mL}$ of rumen fluid from each animal was collected by stomach tube connected to a vacuum pump. Rumen $\mathrm{pH}$ was measured immediately by a portable $\mathrm{pH}$ meter (HANNA instrument HI 8424 microcomputer, Singapore, Singapore) and then filtered through 4 layers of cheesecloth. Forty-five $\mathrm{mL}$ of rumen fluid was mixed with $5 \mathrm{~mL}$ of $1 \mathrm{M} \mathrm{H}_{2} \mathrm{SO}_{4}$ and used for concentration of ammonia nitrogen $\left(\mathrm{NH}_{3}-\mathrm{N}\right)$ and volatile fatty acids (VFAs) analysis using the Kjeltech Auto 1030 Analyzer [12], and high pressure liquid chromatography instruments by water and Novapak model 600E; water mode 1484UV detector; column Novapak C18; column size $3.9 \times 300 \mathrm{~mm}$; mobile phase $10 \mathrm{mM} \mathrm{H}_{2} \mathrm{PO}_{4}$ ( $\mathrm{pH}$ 2.5) according to Samuel et al [15], respectively. Prediction of ruminal methane $\left(\mathrm{CH}_{4}\right)$ production using VFAs proportions was made using the equation of Moss et al [16] as follows:

$$
\begin{aligned}
\mathrm{CH}_{4} \text { production }= & 0.45 \text { (acetate) }-0.275 \text { (propionate) } \\
& +0.4 \text { (butyrate) } \text { unit }
\end{aligned}
$$

Another $1 \mathrm{~mL}$ portion was taken and collected in a plastic bottle to which $9 \mathrm{~mL}$ of $10 \%$ formalin solution was added, it was then kept at $4^{\circ} \mathrm{C}$ for counting bacteria, fungi and protozoa population using the total direct count technique according to the method of Galyen [17]. Ten $\mathrm{mL}$ of Blood were taken from the jugular vein of each animal and immediately kept on ice and transported to the laboratory for analyzing blood urea nitrogen (BUN) using the technique of Crocker [18].

\section{Statistical analysis}

All data were analyzed with analysis of variance according to a $4 \times 4$ Latin square design using the general linear models procedures [19]. Data was analyzed using the model $\mathrm{Y}_{\mathrm{ijk}}=$ $\mu+M_{i}+A_{i}+P_{k}+\varepsilon_{i j k}$, where $Y_{i j k}=$ observation from animal $j$, receiving diet $\mathrm{i}$, in period $\mathrm{k} ; \mu=$ the overall of the mean; $M_{i}=$ the mean effect of dietary treatments $(i=1,2,3,4) ; A_{j}=$ the effect of animal $(j=1,2,3,4) ; P_{k}=$ the effect of period $(k=1$, $2,3,4)$; and $\varepsilon_{\mathrm{ijk}}=$ the residual error. The results were presented as mean values with the standard error of the means. Differences between means with $\mathrm{p}<0.05$ was accepted as statistical differences which treatment means were determined by using the Duncan's new multiple range test [20].

\section{RESULTS}

\section{Chemical composition of the experimental diets}

Feed ingredients, nutrient composition of concentrate and roughages are shown in Table 1. Concentrates were formulated and mixed using local feed ingredients to contain 14.1\% CP. Rice straw has a lower CP (2.8\%) and higher NDF and ADF content ( $75.8 \%$ and $46.8 \%$, respectively). The SG has a greater content of CP and NFC contents (14.7\% and 15.2\%, respectively) while it has a lower content of NDF and ADF concentration (55.7\% and 33.1\%, respectively). In addition, SG contains high level of NFC (15.2\%).

\section{Voluntary feed intake, digestibility and intake of nutrients}

Voluntary feed intake of roughages was different among dietary treatments $(\mathrm{p}<0.01)$ while ratios of roughage intake were increased $(55.8 \%, 64.1 \%, 81.0 \%$, and $100.0 \%$ of DM, respectively) when reducing concentrate supplementation levels (Table 2). Concentrate supplementation at $0.5 \%$ BW with SG showed a greater feed intake, nutrient digestibility and nutrients intake compared to $1.0 \%$ BW concentrate fed with rice straw as the control group. Nutrients digestibility and intake of nutrients were higher with SG feeding when compared to rice straw feeding at the same concentrate supplementation at $1.0 \%$ of BW $(\mathrm{p}<0.01)$. However, there were no significant differences among treatments in the ADF digestibility and ADF intake ( $p>0.05)$. SG improved the nutrients intake and digestibility when compared to RS. Heifers that received the SG/1.0C diet had a greater total feed intake, digestibility, and nutrients intake while SG/0.5C and TSG were better but similar to $\mathrm{RS} / 1.0 \mathrm{C}$, respectively.

\section{Rumen fermentation characteristics and blood metabolites}

Table 3 shows that acetic acid, $\mathrm{NH}_{3}-\mathrm{N}$ concentration and fungi population were increased with decreasing concentrate supplementation $(\mathrm{p}<0.05)$ while it decreased propionic acid and protozoal numbers $(\mathrm{p}<0.05)$. Propionic acid, total VFAs, and bacterial population were the highest values with heifer receiving SG/1.0C diet $(\mathrm{p}<0.05)$. The $\mathrm{CH} 4$ production was decreased with SG/1.0C as compared to RS/1.0C diet $(\mathrm{p}<0.05)$. The TSG group has the highest value of acetic acid, $\mathrm{NH}_{3}-\mathrm{N}$ and fungal population while they have the lowest protozoal population 
Table 2. Effect of dietary treatments on feed intake, nutrient digestibility and nutrient intake in dairy heifers

\begin{tabular}{|c|c|c|c|c|c|}
\hline \multirow{2}{*}{ Items } & \multicolumn{4}{|c|}{ Treatments ${ }^{1)}$} & \multirow{2}{*}{ SEM } \\
\hline & $\mathrm{RS} / 1.0 \mathrm{C}$ & SG/1.0C & SG/0.5C & TSG & \\
\hline \multicolumn{6}{|l|}{ Roughage intake } \\
\hline $\mathrm{kg}$ of $\mathrm{DM} / \mathrm{d}$ & $2.9^{d}$ & $4.1^{c}$ & $4.7^{\mathrm{b}}$ & $5.2^{\mathrm{a}}$ & 0.05 \\
\hline$\%$ of BW & $1.4^{\mathrm{d}}$ & $1.9^{c}$ & $2.1^{\mathrm{b}}$ & $2.4^{\mathrm{a}}$ & 0.02 \\
\hline \multicolumn{6}{|l|}{ Concentrate intake } \\
\hline $\mathrm{kg}$ of $\mathrm{DM} / \mathrm{d}$ & 2.2 & 2.2 & 1.1 & - & - \\
\hline$\%$ of BW & 1.0 & 1.0 & 0.5 & - & - \\
\hline \multicolumn{6}{|l|}{ Total feed intake } \\
\hline $\mathrm{kg}$ of $\mathrm{DM} / \mathrm{d}$ & $5.2^{c}$ & $6.4^{\mathrm{a}}$ & $5.8^{b}$ & $5.2^{c}$ & 0.05 \\
\hline$\%$ of BW & $2.4^{c}$ & $2.9^{\mathrm{a}}$ & $2.6^{\mathrm{b}}$ & $2.4^{c}$ & 0.02 \\
\hline \multicolumn{6}{|l|}{ Nutrient digestibility (\%) } \\
\hline Dry matter & $64.2^{c}$ & $70.2^{\mathrm{a}}$ & $66.5^{b}$ & $62.5^{d}$ & 0.21 \\
\hline Organic matter & $64.0^{c}$ & $70.8^{\mathrm{a}}$ & $67.6^{b}$ & $63.6^{c}$ & 0.12 \\
\hline Crude protein & $66.4^{b}$ & $79.7^{\mathrm{a}}$ & $78.3^{\mathrm{a}}$ & $77.1^{\mathrm{a}}$ & 0.40 \\
\hline Neutral detergent fiber & $57.5^{d}$ & $65.3^{\mathrm{a}}$ & $63.0^{b}$ & $61.3^{c}$ & 0.11 \\
\hline Acid detergent fiber & $51.8^{\mathrm{b}}$ & $56.1^{\mathrm{a}}$ & $55.0^{\mathrm{a}}$ & $52.7^{b}$ & 0.17 \\
\hline \multicolumn{6}{|l|}{ Nutrient intake (kg/d) } \\
\hline Dry matter & $3.3^{c}$ & $4.5^{\mathrm{a}}$ & $3.9^{\mathrm{b}}$ & $3.3^{c}$ & 0.04 \\
\hline Organic matter & $2.9^{c}$ & $4.1^{\mathrm{a}}$ & $3.6^{\mathrm{b}}$ & $3.0^{c}$ & 0.04 \\
\hline Crude protein & $0.3^{b}$ & $0.7^{\mathrm{a}}$ & $0.7^{\mathrm{a}}$ & $0.6^{\mathrm{a}}$ & 0.01 \\
\hline Neutral detergent fiber & $1.5^{b}$ & $1.8^{\mathrm{a}}$ & $1.8^{\mathrm{a}}$ & $1.8^{\mathrm{a}}$ & 0.01 \\
\hline Acid detergent fiber & 0.9 & 0.9 & 0.9 & 0.9 & 0.002 \\
\hline
\end{tabular}

RS, rice straw; SG, sweet grass; TSG, total sweet grass; SEM, standard error of the means; DM, dry matter; BW, body weight.

1) RS/1.0C, RS fed on ad libitum+1.0\% BW of concentrate; SG/1.0C, SG fed on ad libitum $+1.0 \%$ BW of concentrate; SG/0.5C, SG fed on ad libitum+ $0.5 \%$ BW of concentrate; TSG, total SG fed on ad libitum.

abcd different among treatment means $(p<0.05)$.

$(\mathrm{p}<0.05)$. Ruminal $\mathrm{pH}$, butyric acid concentration and BUN levels were not affected by the experimental diets $(\mathrm{p}>0.05)$.

\section{DISCUSSION}

\section{Chemical composition of the experimental diets}

$\mathrm{RS}$ was lower in $\mathrm{CP}$ and higher in fibrous contents compared to SG, especially the CP and carbohydrate contents (higher in NFC and lower NDF, ADF contents). This is due to it being a leafier grass and having a higher leaf to stem ratio that reflected on higher nutritive values. Other using dwarfs Napier grass with leafier grass, also showed high nutritive values [10,21-24].

Voluntary feed intake, digestibility and intake of nutrients As the result of feed intake, concentrate could be fed at 0.5\% BW with SG-based when compared to $1.0 \%$ BW with RSbased in heifer feeding. It appears that SG could reduce the use of concentrate supplementation without negative effect on the amount of feed uptake, nutrient digestibility and intake of nutrients. These results are in accordance with previous experiments which showed that SG was a high quality rough-
Table 3. Effect of dietary treatments on rumen fermentation and blood urea nitrogen concentration in dairy heifers

\begin{tabular}{|c|c|c|c|c|c|}
\hline \multirow{2}{*}{ Items } & \multicolumn{4}{|c|}{ Treatments ${ }^{1)}$} & \multirow{2}{*}{ SEM } \\
\hline & \multicolumn{3}{|c|}{$\mathrm{RS} / 1.0 \mathrm{C} \mathrm{SG} / 1.0 \mathrm{C} \mathrm{SG} / 0.5 \mathrm{C}$} & \multirow{2}{*}{$\begin{array}{c}\text { TSG } \\
6.6\end{array}$} & \\
\hline Ruminal pH & 6.3 & 6.5 & 6.5 & & 0.14 \\
\hline Total VFAs (mg/dL) & $97.0^{\mathrm{b}}$ & $100.0^{\mathrm{a}}$ & $99.5^{\mathrm{a}}$ & $91.6^{c}$ & 0.14 \\
\hline \multicolumn{6}{|l|}{ Molar of VFAs (\%) } \\
\hline Acetic acid & $66.5^{b}$ & $63.3^{c}$ & $66.9^{b}$ & $68.6^{\mathrm{a}}$ & 0.26 \\
\hline Propionic acid & $24.1^{b}$ & $27.0^{\mathrm{a}}$ & $23.7^{\mathrm{b}}$ & $21.9^{c}$ & 0.22 \\
\hline Butyric acid & 9.4 & 9.7 & 9.4 & 9.5 & 0.04 \\
\hline $\mathrm{CH}_{4}(\mathrm{mmol} / 100 \mathrm{~mol})$ & $27.1^{b}$ & $24.9^{\mathrm{a}}$ & $27.3^{b}$ & $28.6^{b}$ & 0.21 \\
\hline Ammonia-nitrogen (mg\%) & $21.2^{c}$ & $20.4^{c}$ & $25.1^{b}$ & $29.7^{\mathrm{a}}$ & 0.47 \\
\hline Blood urea nitrogen (mg/dL) & 13.9 & 14.5 & 14.4 & 15.5 & 0.51 \\
\hline \multicolumn{6}{|c|}{ Rumen microbe population (cell/mL) } \\
\hline Bacteria $\left(\times 10^{11}\right)$ & $30.8^{c}$ & $37.5^{\mathrm{a}}$ & $34.2^{b}$ & $30.3^{c}$ & 0.76 \\
\hline Fungi $\left(\times 10^{6}\right)$ & $2.5^{c}$ & $5.0^{b}$ & $6.5^{\mathrm{ab}}$ & $8.0^{\mathrm{a}}$ & 0.35 \\
\hline Protozoa $\left(\times 10^{5}\right)$ & $10.8^{\mathrm{ab}}$ & $11.3^{\mathrm{a}}$ & $8.3^{b}$ & $6.0^{c}$ & 0.69 \\
\hline
\end{tabular}

RS, rice straw; SG, sweet grass; TSG, total sweet grass; SEM, standard error of the means; VFAs, volatile fatty acids; BW, body weight.

1) RS/1.0C, RS fed ad libitum+1.0\% BW of concentrate; SG/1.0C, SG fed ad libitum+1.0\% BW of concentrate; SG/0.5C, SG fed ad libitum $+0.5 \%$ BW of concentrate; TSG, total SG fed ad libitum.

${ }^{a b c}$ Different among treatment means $(p<0.05)$.

age, especially as it has the lowest content of NDF and ADF when compared to Ruzi, Guinea and Napier Pakchong1 grass at a similar age of regrowth. This resulted in having the highest degradability and accumulated gas production, using in vitro gas production technique. Moreover, it was found that higher quality roughage could decrease levels of concentrate supplementation [10]. The results of this experiment confirmed that voluntary feed intake of roughage, nutrient digestibility and nutrients intake were significantly related to the quality of roughage as NRC, [14] presented that NDF and ADF content were highly related to DM intake and digestibility of roughage. The current results were according to those of previous studies which showed feeding higher quality roughage could increase feed efficiency in ruminants [5,24-26]. Corea et al [26] also found that using Cow-pea as a high quality roughage could reduce the $\mathrm{CP}$ content in concentrate from $17.0 \%$ to $15.5 \%$ without altering the feed digestibility, milk production, and milk components of lactating dairy cows. It also agreed with the findings of Wanapat et al [5] that higher quality roughage achieved using the tropical legume (Phaseolus calcaratus) mixed with Ruzi grass could improve DM intake, nutrient digestibility and milk production. Moreover, it could be used to reduce the amount of concentrate supplementation without adversely effect on rumen fermentation characteristics and milk production in tropical dairy cows. Therefore, quality of roughage is very important to the improvement of feed intake and feed utilization efficiency in ruminant feeding to ensure efficient rumen fermentation and production. 


\section{Rumen fermentation characteristics and blood metabolites}

Rumen fermentation parameters such as $\mathrm{pH}, \mathrm{NH}_{3}-\mathrm{N}$, VFAs, $\mathrm{CH}_{4}$, rumen microbe population and BUN were measured to determine the relationship between the dietary treatments and rumen ecology. As the results, rumen $\mathrm{pH}$ and $\mathrm{NH}_{3}-\mathrm{N}$ were within normal range of 6.3 to 7.2 and 15 to $30 \mathrm{mg} \%$, respectively [27-29]. However, $\mathrm{NH}_{3}-\mathrm{N}$ tended to increase with the increasing of SG intake. It was found that the utilization of high protein forage needs carbohydrate (starch and sugar) to be synchronized for efficient microbial protein production with a decrease in $\mathrm{NH}_{3}-\mathrm{N}$ concentration [30]. In this experiment, it was found that reducing carbohydrate supply from concentrates resulted in increased $\mathrm{NH}_{3}-\mathrm{N}$. The feeding of SG/0.5C showed similar response in these parameters with $\mathrm{RS} / 1.0 \mathrm{C}$. Using higher quality roughage provided more nutrients to rumen microbes for growth and resulted in increased microbial population and rumen fermentation end-products expressed in total VFAs and propionic acid concentration. Total VFA, propionic acid, bacterial and protozoal populations were highest in the heifers which received SG/1.0C as related with feed intake and digestibility as compared with RS/1.0C. Moreover, it could decrease $\mathrm{CH} 4$ emission that might be due to the nutrient composition of roughage influencing on methane yield, particularly hexose fermented and VFAs during the fermentation process in the rumen. Increasing of propionate with decreasing of acetate and butyrate by increasing of NFC in the diet resulted in decreased methane production. Forages that have a high content of NFC, generally support fermentation that increase production of propionate, which competes for hydrogen with methane production. Moreover, forages that have less NDF content could increase digestibility resulting in producing less methane $[1,31,32]$.

Nevertheless, it was found that decreasing concentrate intake would decrease the protozoal population. The number of protozoa was related to level of concentrate feeding with reduction of concentrate leading to decreased protozoal population. Jouany [32] reported that dietary factors, such as roughage to concentrate ratio, forage quality and level of feeding influenced protozoal populations. Another experiment using cassava hay as high quality roughage to reduce concentrate supplementation resulted in improved rumen ecology, particularly increased rumen bacterial and decreased protozoal population, which was associated with enhanced feeds digestibility, milk yield and milk components in dairy cows [8]. This agrees with Martinez et al [33] who found that in sheep a high ratio of concentrate feeding (30:70, R:C ratio) increased total number of protozoa as compared to a low ratio of concentrate (70:30, R:C ratio). In this case, reducing concentrate supplementation and therefore reducing starch and sugar that are the main feed resources for protozoa resulted in decreased protozoal growth. In addition, the populations of fungi were increased by reducing of concentrate supplementation due to increasing the roughage intake improved growing conditions of fungi. Kamra et al [34] reported that the fungal growth was stimulated by the high fiber diets of buffalo when compared to high concentrate diets which rich in non-structural carbohydrates. These numbers of fungi propose to get adhered to the feed particle and related to the digestion efficiency in ruminants [35]. Therefore, it could explain why the highest numbers of fungi were associated with the total SG feeding, with better NDF digestibility than an $\mathrm{RS} / 1.0 \mathrm{C}$. The current study revealed that rumen microorganism populations were highly related to nutrient digestibility, which has a significant role in feed degradation in the rumen, particularly bacterial and fungal populations [36,37]. Moreover, this study suggests that feeding of concentrate supplementation at $0.5 \% \mathrm{BW}$ with good quality roughage would support efficient rumen fermentation as resulted in the fermentation end-products.

\section{CONCLUSION}

In conclusion, $1.0 \% \mathrm{BW}$ of concentrate supplementation with SG improves feed utilization and rumen fermentation. Higher quality roughage could reduce concentrate supplementation when compared to lower quality roughage. High level of roughage feeding, in which $0.5 \%$ BW of concentrate supplementation with SG is recommended. Nevertheless, future studies should be conducted provide more data on its feeding value to produce milk and meat.

\section{CONFLICT OF INTEREST}

We certify that there is no conflict of interest with any financial organization regarding the material discussed in the manuscript.

\section{ACKNOWLEDGMENTS}

The authors would like to thank the Tropical Feed Resources Research and Development Center (TROFREC), Department of Animal Science, Faculty of Agriculture, Khon Kaen University, Thailand, Thailand Research Fund (TRF) through the Royal Golden Jubilee Ph.D. Scholarship, TRF-IRG5980010 and TRF-IRN57W0002, for supporting the research budgets and the use of the research facilities.

\section{REFERENCES}

1. Knapp JR, Laur GL, Vadas PA, Weiss WP, Tricarico JM. Invited review: Enteric methane in dairy cattle production: Quantifying the opportunities and impact of reducing emissions. J Dairy Sci 2014;97:3231-61. 
2. Wanapat M, Cherdthong A, Phesatcha K, Kang S. Dietary sources and their effects on animal production and environmental sustainability. Anim Nutr 2015;1:96-103.

3. Wanapat M, Khampa S. Effect of cassava hay in high quality feed block as anthelmintics in steers grazing on ruzi grass. Asian-Australas J Anim Sci 2006;19:695-8.

4. Chase LE, Grant RJ. High forage rations - What do we know? Proceedings of the Cornell Nutrition Conference. Syracuse, NY, USA; 2013.

5. Wanapat M, Foiklang S, Phesatcha K, et al. On-farm feeding interventions to increase milk production in lactating dairy cows. Trop Anim Health Prod 2017;49:829-33.

6. Yammeun-art S, Somrak P, Phatsara C. Effect of the ratio of maize cob and husk to Napier Pakchong 1 silage on nutritive value and in vitro gas production of rumen fluid of Thai native cattle. Anim Prod Sci 2017;57:1603-6.

7. Yang WZ, Beauchemin KA. Altering physically effective fiber intake through forage proportion and particle length: chewing and ruminal pH. J Dairy Sci 2007;90:2826-38.

8. Wanapat M, Puramongkon T, Siphuak W. Feeding of cassava hay for lactating dairy cows. Asian-Australas J Anim Sci 2000; 13:478-82.

9. Akins MS, Shaver RD. Influence of corn silage hybrid type on lactation performance by Holstein dairy cows. J Dairy Sci 2014;97:7811-20.

10. Mapato C, Wanapat M. Fermentation characteristics of tropical grass using in vitro gas production technique. Proceeding of the 17th Asian-Australasian Association of Animal Production Societies Animal Science Congress; 2016. pp. 366-72.

11. Wanapat M, Gunun P, Anantasook N, Kang S. Changes of rumen $\mathrm{pH}$, fermentation and microbial population as influenced by different ratios of roughage (rice straw) to concentrate in dairy steers. J Agric Sci (Cambridge) 2014;152:675-85.

12. AOAC. Official methods of analysis, 19 th edition. Animal Feed: Association of Official Analytical Chemists, Gaithersburg, MD, USA. AOAC International; 2012.

13. Van Soest PJ, Robertson JB, Lewis BA. Methods for dietary fiber neutral detergent fiber, and non-starch polysaccharides in relation to animal nutrition. J Dairy Sci 1991;74:3583-97.

14. NRC (National Research Council). Nutrient requirements of dairy cattle. 6th Rev. Ed. Washington, DC, USA: National Academy of Sciences; 2001.

15. Samuel M, Sagathewan S, Thomus J, Mathen G. An HPLC method for estimation of volatile fatty acids of rumen fluid. Indian J Anim Sci 1997;67:805-7.

16. Moss AR, Jouany P, Newbold J. Methane production by ruminants: its contribution to global warming. Ann Zootech 2000; 49:231-53.

17. Galyen M. Laboratory procedures in animal nutrition research. Las Cruces, NM, USA: New Mexico State University; 1989.

18. Crocker CL. Rapid determination of urea-nitrogen in serum or plasma without deproteinization. Am J Med Technol 1967;
33:361-5.

19. SAS. What's New in SAS 9.0, 9.1, 9.1.2, and 9.1.3. Cary, NC, USA: SAS Institute Inc.; 2004.

20. Steel RGD, Torrie JH. Principles and procedures of statistics: a biometrical approach. 2nd edition. New York, NY, USA: McGraw-Hill Book Co; 1980.

21. Yokota H, Fujii Y, Oshima M. Nutritional quality of Napier grass (Pennisetum purpureum, Schum.) silage supplemented with molasses and rice bran by goats. Asian-Australas J Anim Sci 1998;11:697-701.

22. Halim RA, Shampazurini S, Idris AB. Yield and nutritive quality of nine Napier grass varieties in Malaysia. Mal J Anim Sci 2013; $16: 37-44$

23. Wangchuk K, Rai K, Nirola H, Dendup C, Mongar D. Forage growth, yield and quality responses of Napier hybrid grass cultivars to three cutting intervals in the Himalayan foothills. Trop Grassl - Forrajes Tropicales 2015;3:142-50.

24. Zailan MZ, Yaakub H, Jusoh S. Yield and nutritive value of four Napier (Pennisetum purpureum) cultivars at different harvesting ages. Agric Biol J North Am 2016;7:213-9.

25. Chanthakhoun V, Wanapat M, Wachirapakorn C, Wanapat S. Effect of legume (Phaseolus calcaratus) hay supplementation on rumen microorganisms, fermentation and nutrient digestibility in swamp buffalo. Livest Sci 2011;140:17-23.

26. Corea EE, Aguilara JM, Alasa NP, et al. Effects of dietary cowpea (Vigna sinensis) hay and protein level on milk yield, milk composition, $\mathrm{N}$ efficiency and profitability of dairy cows. Anim Feed Sci Technol 2017;226:48-55.

27. Van Soest PJ. Nutritional ecology of the ruminant, 2nd ed. Ithaca, NY, USA: Cornell University Press; 1994.

28. Wanapat M, Pimpa O. Effect of ruminal $\mathrm{NH}_{3}-\mathrm{N}$ levels on ruminal fermentation, purine derivatives, digestibility and rice straw intake in swamp buffaloes. Asian-Australas J Anim Sci 1999;12:904-7.

29. Kang S, Wanapat M, Cherdthorng A. Effect of banana flower powder supplementation as a rumen buffer on rumen fermentation efficiency and nutrient digestibility in dairy steers fed a high-concentrate diet. Anim Feed Sci Technol 2014;196:3241.

30. Wanapat M, Kang S. Cassava chip (Manihot esculenta Crantz) as an energy source for ruminant feeding. Anim Nutr 2015;1: 266-70.

31. Benchaar C, Pomar C, Chiquette J. Evaluation of dietary strategies to reduce methane production in ruminants: a modelling approach. Can J Anim Sci 2001;81:563-74.

32. Jouany JP. Effects of diet on populations of rumen protozoa in relation to fibre digestion. In: Nolan JV, Leng RA, Demeyer DI, editors. The roles of protozoa and fungi in ruminant digestion. Armidale, Australia: Penambul Books; 1989.

33. Martinez ME, Ranilla MJ, Tejido ML, Saro C, Carro MD. Comparison of fermentation of diets of variable composition and microbial populations in the rumen of sheep and Rusitec fer- 
menters. II. Protozoa population and diversity of bacterial communities. J Dairy Sci 2010;93:3699-712.

34. Kamra DN. Rumen microbial ecosystem. Curr Sci 2005;89;126.

35. Akin DE, Rigsby LL. Mixed fungal populations and lignocellulosic tissue degradation in the bovine rumen. Appl Environ Microbiol 1987;53:1987-95.
36. Hungate RE. A roll tube method for cultivation of strict anaerobes. In: Norris JR, Ribbons DW, editors. Methods in microbiology. NY, USA: Academic Press; 1969. pp. 117-313.

37. Russell JB, Muck RE, Weimer PJ. Quantitative analysis of cellulose degradation and growth of cellulolytic bacteria in the rumen. FEMS Microbiol Ecol 2009;67:183-97. 